Asian J. Med. Biol. Res. 2018, 4 (1), 132-136; doi: 10.3329/ajmbr.v4i1.36831

\author{
Asian Journal of \\ Medical and Biological Research \\ ISSN 2411-4472 (Print) 2412-5571 (Online) \\ www.ebupress.com/journal/ajmbr
}

\title{
Article \\ Seroprevalence of infectious bronchitis virus in different types of chicken in Bangladesh
}

\author{
Zafar Ahmed Bhuiyan ${ }^{1}$, Md. Giasuddin ${ }^{2} *$ and Zahed Uddin Mahmood Khan ${ }^{1}$ \\ ${ }^{1}$ Department of Botany, Jahangirnagar University, Savar, Dhaka-1341, Bangladesh \\ ${ }^{2}$ Animal Health Research Division, Bangladesh Livestock Research Institute (BLRI), Savar, Dhaka-1341, \\ Bangladesh
}

*Corresponding author: Md Giasuddin, Animal Health Research Division, Bangladesh Livestock Research Institute (BLRI), Savar, Dhaka-1341, Bangladesh. E-mail: mgias04@yahoo.com

Received: 07 March 2018/Accepted: 22 March 2018/ Published: 29 March 2018

\begin{abstract}
Infectious bronchitis virus (IBV) is a highly contagious viral disease of the chicken. It is possibly the most economically important viral respiratory disease of chicken after Avian Influenza and Newcastle disease. The virus also affects the female reproductive tract, causing poor quality of egg and loss of egg production. The study was conducted in four types of chicken (broiler, layer, sonali and Deshi) from 7 sub-districts under 4 districts of Bangladesh. Total 833 blood samples from 103 farms were collected and subjected to indirect ELISA test by commercially available IBV ELISA kits to detect specific antibodies against IBV. In overall $59.30 \%$ seroprevalence observed, $23.82 \%$ was found in broiler, $97.87 \%$ in layer, $71.83 \%$ in sonali and $83.46 \%$ in Deshi types of chickens. Broiler samples showed lowest seroprevalence with high CV (CV\%=171.38), among them $76.18 \%$ were not seroconvert because of high maternal antibody or poor vaccine response. Layers showed highest seroprevalence with CV\% 58.86 that is $18.00 \%$ chickens shows titer above 14000 which indicated field infection. Deshi chickens were not commercially vaccinated even though they had high seroprevalence rates $83.46 \%$ with mean titer 5333 and CV\% 79.88, indicating that IBV is circulating as endemic diseases in the selected areas. Sonali chickens now reared as commercial chicken, have lower seroprevalence rates with mean titer 3160 , CV\% 128.39 indicating that these birds were not properly vaccinated as they required. To prevent the flocks from IBV, live and attenuated vaccination is required according to circulating strains.
\end{abstract}

Keywords: infectious bronchitis virus; seroprevalence; chicken

\section{Introduction}

Avian infectious bronchitis (IB) is an acute, highly contagious viral disease of poultry, clinically manifested by respiratory sign like tracheal rales, sneezing and coughing (Cavanagh and Naqi, 2003). Poultry of all ages can be infected by infectious bronchitis virus (IBV) (Barua et al., 2006). Globally IB is considered as one of the top economically important poultry disease as it reduces egg production, degrade egg shell quality and renders less hatchability and poor body weight gain, and poor feed conversion ratio (FCR) in broiler (Cavanegh, 2008). The disease can often be a component of mixed infection along with other pathogen like Mycoplasma and E. coli that produces air saculitis, which may result in meat condemnation during processing (Ali et al., 2015). The IBV under genus Gammacoronavirus and family of Coronaviridae (Abdel-Moneim et al., 2006). Epithelial cells of respiratory tract, reproductive and urinary tract is the primary target of IBV (Balasubramenia et al., 2013). Some IBV strains can replicate in gastrointestinal tract that can cause up to $44 \%$ mortality (Cavanagh, 2005). In some other cases IBV infection in proventriculus may result in $75 \%$ to $100 \%$ mortality in young birds (Yu et al., 2001). There are more than 20 known serotype within IBV (Mass, Conn, Ark, Geofgia, Delware-e/072/92 and California) recognized globally (Lee and Jckwood, 2000). On the basis of cross reaction IBV serotypes are 
different. Most of the serotypes and genotypes of IBV do not produce cross protection (Jackwood, 2012; Cavanagh et al., 1992). In spite of routinely vaccination against IBV, there may be still disease outbreak in vaccinated flock, as it does not give cross protection against antigenically different serotype and variant strain of virus (Callison et al., 2006). So, to get best protection against IBV, it is very important to determine the antigenic nature of specific IBV serotype in a geographic region, which is very helpful for proper vaccine selection. The present study was done to determine the seroprevalence status and antibody titer level of IBV in broiler, layer, sonali and Deshi chickens of Bangladesh.

\section{Materials and Methods}

\subsection{Study area}

The study was conducted in the Bogra Sadar sub-district of Bogra district, Sreepur sub-district of Gazipur district, Sadar sub-district of Jamalpur district, and Valuka, Trishal, Fulbariya and Muktagacha sub-district of Mymensingh district. In all seven sub-district area poultry population are high. The study was conducted from December 2014 to March 2016 for the duration of 16 months.

\subsection{Study population}

Blood samples were collected from Deshi chickens (indigenous, non-descriptive) that are rearing in scavenging system, broiler, layer and sonali chicken from each sampling area. Households were selected randomly based on their participation of Deshi chicken rearing, broiler, layer and sonali chicken farming activity. All flock information and history was recorded in sampling form. A total 833 blood samples from 103 farms were collected. Among them Deshi chicken (household-20, sample-133), Broiler (Farm-47, sample-382), layer (Farm-21, sample-247) and sonali (Farm-15, sample-71) were considered for sampling.

\subsection{Sample collection and preservation}

Blood samples were collected aseptically from the wing vein of each chicken. About 1.5-2 ml of blood samples were collected in sterile disposable syringe. After collection of blood, syringe was kept stand to allow blood to clot at room temperature and separation of serum. When serum was separated it was centrifuged at $1500 \times g$ and transferred in sterile eppendorf tubes. Then the clear serum samples were stored in $-20^{\circ} \mathrm{C}$ refrigerator until test was done. The laboratory test was performed in National Reference Laboratory for Avian Influenza, Bangladesh Livestock Research Institute, Savar, Dhaka.

\subsection{Serological test}

Serological test were performed by indirect ELISA (Enzyme linked immune sorbent assay) test method, to measure antibody titer level against IBV. Test was performed with commercial ELISA kit (BioChek, Holland). All conditions were standardized according to kit manufacturer instructions using pre-coated ELISA plate and ready to use reagents.

In brief, serum samples were diluted in 1:500 with sample diluent, positive control and negative control were added into antigen coated microtiter plated and incubated at room temperature $23^{\circ} \mathrm{C}$ for $30 \mathrm{~min}$. After incubation, plates were washed 5 times with wash buffer and $100 \mu l$ conjugate reagent was added to the plate. The plate was incubated at room temperature $23^{\circ} \mathrm{C}$ for $30 \mathrm{~min}$. The plates were washed and added, incubated at room temperature $23^{\circ} \mathrm{C}$ for $15 \mathrm{~min}$ after adding $100 \mu \mathrm{l}$ substrate reagent. Finally $100 \mu \mathrm{l}$ stop solution was added to stop the reaction. The ELISA plate was read by ELISA reader (Opsys MR, UK) at $405 \mathrm{~nm}$ filter absorbance within 15 minutes after adding stop solution.

\subsection{ELISA test validation interpretation}

After taking test result, test validity was checked by comparing optical density (OD) value for the test and certificate $\mathrm{OD}$ value from manufactures references (mean negative control $\mathrm{OD}=0.145$, mean positive control $\mathrm{OD}=0.708)$. Calculation of sample/positive $(\mathrm{S} / \mathrm{P})$ ratio by $\{($ mean of test sample - mean of negative control) $\}$ / $\{($ mean of positive control - mean of negative control) $\}$. For determination of antibody titer following equation were used $\log _{10}{ }^{\text {Titer }}=1.0 \log _{10}{ }^{(\mathrm{S} / \mathrm{P})}+3.62$. For IBV antibody titer interpretation, samples with $\mathrm{S} / \mathrm{P}$ value $\geq 0.2$ (titer $\geq 834$ ) was considered as seropositive and $\mathrm{S} / \mathrm{P}$ value $\leq 0.199$ (Titer $\leq 833$ ) was considered negative.

\section{Results}

A total of 833 serum samples were tested which were collected from 103 number of farms. All the collected serum samples were undertaken for ELISA test and found overall $59.30 \%$ seroprevalence rates of IBV in selected regions of Bangladesh. Among four types of chickens, seroprevalence was found highest that was 
97.57\% (241/247) in layer poultry. In case of Deshi poultry $83.46 \%$ (111/133) samples were found seropositive, for sonali chickens $71.83 \%$ (51/71) samples were seropositive and lowest seroprevalence $23.82 \%$ (91/382) was found in broiler chickens (Table 1).

Highest mean titer of IBV antibody was found in layer and mean titer was 8919.70 with CV\% 58.86 . In case of sonali mean titer was found 3160.71, with CV\% 128.39, for Deshi chickens mean titer was 5333.82 with CV\% 79.88, and lowest mean titer with highest CV\% was found in broiler 722.76, 171.38\% respectively (Table 2) .

Titer range 0-833 considered as negative. In layer poultry majority of the seropositive samples are within titer group 2000-20000, that was highest among four types of chickens. High titer range may be due to field infection. In case of Deshi chickens maximum are in titer range of 2000-12000, few others are in 12000-18000 titer range group. In case of sonali, out of 71 serum samples 20 samples are in negative titer group, larger portion of samples (47/71) are in titer group of 834-10000. Out of 382 broiler serum samples 291 are in negative titer range group, rest samples (91/382) are in 834-8000 titer range group.

Table 1. The seroprevalence of IBV in broiler, layer, sonali and Deshi chicken.

\begin{tabular}{lllllll}
\hline $\begin{array}{l}\text { Type of } \\
\text { chicken }\end{array}$ & $\begin{array}{l}\text { Farm } \\
(\mathbf{n})\end{array}$ & $\begin{array}{l}\text { Tested sample } \\
(\mathbf{n})\end{array}$ & $\begin{array}{l}\text { Positive } \\
\text { sample (n) }\end{array}$ & Seroprevalence (\%) & Mean titer & CV\% \\
\hline Broiler & 47 & 382 & 91 & 23.82 & 722.76 & 171.38 \\
Layer & 21 & 247 & 241 & 97.57 & 8919.70 & 58.86 \\
Sonali & 15 & 71 & 51 & 71.83 & 3160.71 & 128.39 \\
Deshi & 20 & 133 & 111 & 83.46 & 5333.82 & 79.88 \\
Total= & $\mathbf{1 0 3}$ & $\mathbf{8 3 3}$ & $\mathbf{4 9 4}$ & $\mathbf{5 9 . 3 0}$ & & \\
\hline
\end{tabular}

Table 2. Seroprevalence distribution among different titer range group of layer, Deshi, broiler and sonali chicken.

\begin{tabular}{lllll}
\hline $\begin{array}{l}\text { Titer range } \\
\text { (mean titer) }\end{array}$ & Layer $(\mathbf{n})$ & Deshi $(\mathbf{n})$ & Sonali $(\mathbf{n})$ & Broiler $(\mathbf{n})$ \\
\hline $0-833$ & 6 & 22 & 20 & 291 \\
$834-2000$ & 7 & 11 & 17 & 52 \\
$2001-4000$ & 37 & 25 & 18 & 27 \\
$4001-6000$ & 34 & 31 & 5 & 9 \\
$6001-8000$ & $42(17.02 \%)$ & $12(9.02 \%)$ & $4(5.63 \%)$ & $3(0.78 \%)$ \\
$8001-10000$ & $27(10.93 \%)$ & $10(7.52 \%)$ & $3(4.22 \%)$ & - \\
$10001-12000$ & $26(10.52 \%)$ & $11(8.27 \%)$ & $4(5.63 \%)$ & - \\
$12001-14000$ & $23(9.31 \%)$ & $3(2.25 \%)$ & - & - \\
$14001-16000$ & $18(7.28 \%)$ & $5(3.75 \%)$ & - & - \\
$16001-18000$ & $11(4.45 \%)$ & $3(2.25 \%)$ & - & - \\
$18001-20000$ & $6(2.43 \%)$ & - & - & - \\
$20001-22000$ & $7(2.83 \%)$ & - & - & - \\
$22001-A b 0 v e$ & $3(1.21 \%)$ & - & - & $\mathbf{3 8 2}$ \\
Total & $\mathbf{2 4 7}$ & $\mathbf{1 3 3}$ & $\mathbf{7 1}$ & \\
\hline
\end{tabular}

\section{Discussion}

The chickens of selected flocks were carried overall $59.30 \%$ antibodies with their serum. Present study reveals that among four types of chicken, layer chickens contains highest (97.57\%) seroprevalence as well as highest mean titer (8919.70) Table 1. The findings is strong agreement with the report of Barua et al. (2006), who demonstrated overall 58.00\% seroprevalence of IBV in Fayoumi, RIR and local chickens of government poultry farms of Bangladesh. The results are also supported by the findings of Das et al. (2009), who reported that overall seroprevalence of IBV in Bangladesh is $79.38 \%$, and they found highest mean titer were 9867.29. These results also agreed with the report of previous study conducted by Alam et al. (2003) and Biswas (2004) who found seroprevalence of IBV $92.06 \%$ and $77.83 \%$ respectively. High antibody titer may be due to repeated vaccination of live and killed IBV vaccine in different ages. In broiler and pullets, attenuated vaccines of IBV frequently used and on the other hand killed vaccine mainly used in broiler breeder and layer chicken (Jackwood, 2012; Cavanagh and Gelb, 2008). Deshi chickens reared without any vaccination for prevention of IBV. But they are carrying average 33.08\% of highest antibody titer in titer group 6001 to 18000 . Higher seroprevalence and antibody titer level against IBV in Deshi chickens indicates that IBV is endemic in environment (Bochkov et al., 2006). About 83.46\% seroprevalence rates of IBV were found in Deshi chickens. 
The researcher Barua et al. (2006) also demonstrated 98.00\% Deshi chickens are moving with IBV antibodies without any signs of IBV infections in Bangladesh. Broiler has been reared for a short period of time of 30 to 35 days and the passive immunity against IBV becomes depleted in $6^{\text {th }}$ days of age (Gharaibeh and Mahmoud, 2013). As a results, only $0.78 \%(n=3)$ broiler chickens shown the highest mean in titer group between 6001 and 8000. On the other hand, sonali chicken reared for meat purpose except hatching egg production. They are reared for 60 to 75 days of age with two times vaccinated with attenuated vaccines of IBV. So 5.53\% sonali chickens carried the antibody mean titer in their highest titer group 10001 to 12000 . In case of sonali chicken lower seroprevalence $71.38 \%$ was observed with mean titer 3160 (CV\%, 128.39) which indicates improper vaccination as they required.

\section{Conclusions}

In this study it is evident that, variant types of IBV are prevalent in both meat and egg producing poultry of Bangladesh. As there is high seroprevalence of IBV in Deshi chicken, vaccination can be suggested to all types of poultry. Virus is well circulated in BD environment. Vaccine and biosecurity is required for control the IBV. So, In addition to vaccination, it is necessary to monitor persistent serotype circulating in the field, isolation and characterization of IBV for selection of proper vaccine schedule.

\section{Conflict of interest}

None to declare.

\section{Reference}

Cavanagh D and S Naqi, 2003. Infectious bronchitis. In Diseases of poultry (saif ym, Barnes JH, Fadley AM, Gilson JR, Mcdougald LR \& Suayen DE eds), $11^{\text {th }}$ eds 101-119, Ioea state University prem, anes, Iowa.

Barua H, PK Bisuead, NC Debnath, MN Anwar and BC Dey, 2006. Serosurvey and isolation of infectious bronchitis virus in chicken reared in commercial and semi scavenging system. Bangladesh Microbiol., 23: 114-117.

Cavanegh D and J Gelb, 2008. Infectious bronchitis. In Y.M. saif, H. J. Barnes, J.R. Glisson, A. M.

Abdel-Moneim AS, MF El-kady, BS Ladman and J Gelb, 2006. S1 gene sequence analysis of a nephropathogenic strain of avian infectious bronchitis virus in Egypt. Virol., 3: 1-9.

Balasubramenia A, TR Gupalkrishnamurthy, S Sivaseelan, GA Balasubramaniam and JJ Rajeswar, 2013. Evaluation of an inactivated vaccine for nephropathogenic infectious bronchitis virus. Vet. World, 6: 134138.

Cavanagh D, 2005. Corona viruses in poultry and other birds. Avian Pathol., 34: 439-448.

Yu L, Y Jiang, S Low, Z Wang, SJ Nam, W Liu and J Kweng, 2001. Characterization of three infectious bronchitis virus isolates from china associated with proventriculus in vaccinated chickens. Avian Dis., 45: 416-424.

Lee CW and MW Jackwood, 2000. Evidence of genetic diversity generated by recombination among avian coronation IBV. Arch. Virol., 145: 2135-2148.

Barua H, PK Biswas, MN Anwar, BC Dey and MC Debnath, 2006. Serosurvey and isolation of infectious bronchitis virus in chickens reared in commercial and semi-scavenging systems. Bangladesh Journal of Microbiology, 23: 114-117.

Das SK, MSR Khan and M Das, 2009. Seroprevalence of Infectious Bronchitis in Chicken in Bangladesh. Bangl. J. Med., 7: 249-252.

Alam J, I Koike, M Giasuddin and MM Rahman, 2003. Seroprevalence of poultry diseases in native chickens of Bangladesh. Bangladesh society for Veterinary Education and research (BSVER), publication no. 24, p 26. Bangladesh Agricultural University, Mymensingh.

Biswas PK, 2004. A longitudinal study to identify the cause on the mortality of 'Sonali' birds and broody hen chicks of key beneficiaries in the SLDP-2 area. final report, p.78. Smallholder Livestock development Project-2 (SLDP-2) Applied research project, Chittagong, Bangladesh.

Cavanagh D and J Gelb Jr., 2008. Infectious bronchitis. In: Diseases of poultry, 12th ed. Y. M. Saif, A. M. Fadly, J. R. Glisson, L. R. McDougald, L. K. Nolan, and D. E. Swayne, eds. Blackwell Publishing, Ames, IA. pp. 117-135. 2008.

Jackwood MW, 2012. Review of infectious bronchitis virus around the world. Avian Dis., 56: 634-641.

Bochkov YA, GV Batchenko, LO Shcherbakova, AV Borisov and VV Drygin, 2006. Molecular epizootiology of avian infectious bronchitis virus in Russia. Avian Pathol., 35, 379-393. 
Gharaibeh S and K Mahmoud, 2013. Decay of maternal antibodies in broiler chickens. Poultry Sci., 92: 23332336.

Ali MZ, MM Rahman and S Sultana, 2015. Seroprevalence of Mycoplasma gallisepticum antibody by ELISA and serum plate agglutination test of laying chicken. Vet. World, 8: 9-14.

Callison SA, DA Hilt, TO Boynton, BF Sample, R Robison, DE Swayne and MW Jackwood, 2006. Development and evaluation of a real-time Taqman RT-PCR assay for the detection of infectious bronchitis virus from infected chickens. Journal of Virological Methods, 138: 60-65.

Cavanagh D, PJ Davis, J Cook, D Li, A Kant and G Koch, 1992. Location of the amino acid differences in the S1 spike glycoprotein subunit of closely related serotypes of infectious bronchitis virus. Avian Pathol., 21: $33-43$. 